\title{
合成標準試料を用いたガラスビード/蛍光 $\mathbf{X}$ 線分析 による岩石中の主成分元秦の定量
}

\author{
吉岡 明®，関根孝雄，吉田秀光，野村紘一* \\ (1988 年 6 月 18 日受理)
}

\begin{abstract}
合成標準試料を用いた岩石試料のガラスビード/XRF 分析法を検討した. 日常分析に適用するため, 簡便なガラスビードの作製法を考案した. 合成標準試料は酸化物や炭酸塩などの高純度試薬を均一に混 合し, 調製した。 XRF 測定から合成標準試料のガラスビードの再現性は良好であることを確認した. 合成標準試料と岩石標準試料のガラスビードを用いて検量線を作成したところ，両者とも一致した 1 本 の直線関係が得られた. 合成標準試料のガラスビードから作成した検量線を用いて, 標準岩石中の $\mathrm{Si}$, $\mathrm{Ti}, \mathrm{Al}, \mathrm{Fe}, \mathrm{Mn}, \mathrm{Mg}, \mathrm{Ca}, \mathrm{Na}, \mathrm{K}$ 及び $\mathrm{P}$ の定量を行った結果，推奖值と良い一致を示した. 又, 強熱減量分の多い岩石試料は, 強熱処理した試料に対して本法を適用し, 得られた分析値を強熱減量率 で補正することにより定量が可能であることが分かった. 本法は種↔の岩石試料の実用分析法として有 効であると考えられる。
\end{abstract}

\section{1 緒言}

地球科学に関連した分野では広範囲で多数の岩石試料 の分析が必要とされ, 得られた膨大なデータの解析から 地質構造, 鉱物成因, 資源探査などの研究が進められて いる. 従来, 利用されてきた湿式化学分析は精度の良い 方法であるが，操作に時間がかかることなどの 理由か ら，多数の試料を短時間で処理するには不適当である. このため迅速かつ精度の良い分析方法の開発が要求され てきた。

機器分析のなかで, XRF 分析法は迅速性, 簡便性, 分析者の熟練を必要としないなどの理由から品質管理分 析として急速に広まり, 又岩石試料の定量分析への応用 も研究されてきた，岩石の主成分元素の XRF に拈ける 試料調製法は粉末加圧成型法 (粉末法) と溶融法 (ガラス ビード法）が主に用いられている. 粉末法は XRF 強度 が大きい特徵があるが, 粉体試料の粒度によって XRF 強度がばらつき, 重大な誤差原因となる. 後藤ら 前処理として標準試料と未知試料の粒度を同程度の微粉 末に調製する必要があることを報告している. 日常分析 で種々の試料を処理する場合, 試料粒度を小さくし, そ して均一にすることは作業性が良くないことや污染など の問題がある. 粒子径効果の補正 ${ }^{3)}$ も検討されているが

*三菱金属 (株)中央研究所：330 埼玉県大宮市北袋 町 1-297
目的の定量法として, かならずしも十分な精度が期待で きるとはかぎらない. 一方, ガラスビード法は粒子径効 果や鉱物効果による影響がなくなり, マトリックス効果 も注沟一化され，XRF による精度の良い定量法が報 告されてきている4) 8). しかし, 種々の岩石試料の日常 分析を行ら場合, 適当な標準試料が十分に得られないこ と, 強熱減量の多い試料についての定量法が確立してい ないこと, 又試料調製に要する時間の長さなどが問題と なっている. 本報では, 最も簡便なガラスビードの作製 法を考案し, 定量に対しては, 任意の濃度範囲の検量線 作成が可能な試薬混合による合成標準試料を用いた。更 に強熱減量の多い試料についての定量法についても検討 したので報告する.

$$
2 \text { 実験 }
$$

\section{$2 \cdot 1$ 装置と試薬}

$\mathrm{XRF}$ 装置は 理学電機工業製波長分散型 $3080 \mathrm{E}$ 型, $\mathrm{X}$ 線管球は $\mathrm{Rh}$ 対陰極縱型管球を使用した。本装置は 装置制御とデータ解析をするマイクロコンピューターと 自動試料交換装置を付属している.

試料溶融装置は高周波加熱师型の装置で理学電機工業 製ビードサンプラーを用い，るつほは Pt-Au (5\%) 合 金を使用した。

融戍は無水四ホウ酸リチウム (小宗化学製特級試薬), 合成標準試料の作製に用いた酸化物や炭酸塩などは市販 の特級試薬あるいは高純度試薬を使用した。これらの試 薬は発光分光分析法で不純物がこん跡量 であることを 
確認した。脱泡はく離剤は旭硝子製 フロンガス $13 \mathrm{~B} 1$ $\left(\mathrm{CBrF}_{3}\right)$ を使用した。

\section{2 標準試料}

2・2・1 標準岩石試料用いた岩石標準試料は 15 種 類で，それらの試料名と発行機関を以下に示す.

JG-1, JB-1 : GSJ (Geological Survey of Japan, 地 質調查所）

AGV-1，BGR-1，DTS-1，G-2, GSP-1， PGC-1, MRG-1 : USGS (U. S. Geological Survey, 米国地質 調查所)

SRM 278, 688 : NBS (National Bureau of Standards)

SY-2, SY-3, UM-1, UM-2 : GGRMP (The Canadian Certified Reference Materials Project)

これらの標準岩石試料を顕微鏡で観察すると発行機関 や岩石種によって試料粒度に差が見られた. 特に石英や 黒雲母などの大きな鉱物粒（２00 $\mu \mathrm{m} ）$ を含む試料むあ り，全試料について粒度が一様ではなかった。

2.2.2 合成標準試料 合成標準試料は疑似岩石を目 的として，岩石の主成分である 10 元素を基に酸化物や 炭酸塩などを混合し合成した。使用した試薬は $\mathrm{SiO}_{2}$, $\mathrm{TiO}_{2}, \mathrm{Al}_{2} \mathrm{O}_{3}, \mathrm{Fe}_{2} \mathrm{O}_{3}, \mathrm{MnO}_{2}, \mathrm{MgO}, \mathrm{CaO}, \mathrm{Na}_{2} \mathrm{CO}_{3}$, $\mathrm{K}_{2} \mathrm{CO}_{3}$ 及び $\mathrm{KH}_{2} \mathrm{PO}_{4}$ の 10 種で, めのう乳鉢で微粉

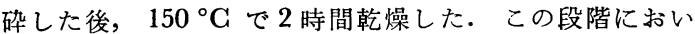
て, 発光分光分析法で各試薬の不純物の確認を行ったと ころ，無視できる程度であった．合成に当たり，一般的 な岩石の化学組成範囲をカバーし, 又各元素の濃度こう 配が得られるように 5 種類の混合比を設定した. 混合は 回転軸が 水平に対し傾きを持った円筒型回転混合機を 使用し，円筒容器及びかくはん子はプラスチック製を用 いた．ひょう量誤差を小さくし，完全混合に近ゔけるた め，少量成分である $\mathrm{MnO}_{2}, \mathrm{KH}_{2} \mathrm{PO}_{4}$ などはあらかじ め $\mathrm{SiO}_{2}$ 粉末で希釈して $1 \%$ 混合粉体を作製し，その 混合粉体から所定量を量り取り，他の試薬粉末と更に混 合希釈することにより調製した。最終的に得られた混合 粉体を $1000{ }^{\circ} \mathrm{C}$ で仮焼きし，炭酸分と水分を除去して合 成標準試料 $(\mathrm{SS} 1 \sim 5)$ とした。これらの合成標準試料の 仮焼き後の重量増加率は，デシケーター中で 24 時間保 存した場合， $0.02 \%$ 以下であった。 又，炭酸分は分析 の結果, こん跡量であった.これらの化学組成は配合值 より計算して求めた. 合成標準試料の化学組成を Table 1 に示す。

\section{$2 \cdot 3$ ガラスビードの作製法}

2.3.1 虽 剤融剂は無水四ホウ酸リチウムを使 用した。この試薬は製造メーカーによって，水分を含ん でいたり，かさ高く量り取り難い，失透しやすいなど差 があったため, 本研究では小宗化学製の試薬を用いた。

しかし，この試薬中には，示差熱・熱天びんの測定結果 より付着水と結合水が確認され，このまま使用すると良 好なガラスビードが得られない。このため, 融剤の管理 として，400 ${ }^{\circ} \mathrm{C}$ 等で脱水しデシヶーター中に保存して使
Table 1 Ghemical composition of synthetic samples

\begin{tabular}{lrrrrr}
\hline Oxide & \multicolumn{1}{c}{ SS1 } & \multicolumn{1}{c}{ SS2 } & \multicolumn{1}{c}{ SS3 } & \multicolumn{1}{c}{ SS4 } & \multicolumn{1}{c}{ SS5 } \\
\hline $\mathrm{SiO}_{2}$ & 23.53 & 41.19 & 56.98 & 68.66 & 79.15 \\
$\mathrm{TiO}_{2}$ & 5.90 & 4.57 & 3.32 & 2.16 & 1.04 \\
$\mathrm{Al}_{2} \mathrm{O}_{3}$ & 23.59 & 17.14 & 11.07 & 5.38 & 1.04 \\
$\mathrm{Fe}_{2} \mathrm{O}_{3}$ & 17.68 & 11.42 & 5.53 & 3.22 & 1.04 \\
$\mathrm{MnO}$ & 0.01 & 0.07 & 0.15 & 0.23 & 0.31 \\
$\mathrm{MgO}$ & 2.37 & 4.59 & 6.65 & 8.69 & 10.41 \\
$\mathrm{CaO}$ & 11.91 & 8.97 & 6.64 & 4.26 & 1.80 \\
$\mathrm{Na}_{2} \mathrm{O}$ & 6.90 & 5.49 & 4.28 & 3.15 & 2.02 \\
$\mathrm{~K}_{2} \mathrm{O}$ & 8.08 & 6.46 & 5.12 & 3.91 & 2.68 \\
$\mathrm{P}_{2} \mathrm{O}_{3}$ & 0.02 & 0.11 & 0.25 & 0.36 & 0.51 \\
\hline
\end{tabular}

All values given as wt $(\%)$.

用することにした．その後の吸湿性は 1 か月間で $0.2 \%$ と無視できる程度であった。

2.3.2 脱泡はく離剤 試料と融剤のみからガラスビ ードを作製すると気泡が入ったり，るつぼからはがれに くい場合がある.このため一般には脱泡はく離剤として 臭化リチウムあるいはヨウ化リチウムが用いられるが， 溶融操作の初期段階で添加するとハロゲンが揮散して効 果が減少すること9), 又試薬の潮解性や長期間使用によ るるつぼの劣化が問題となる．このため旭硝子製フロン ガス 13B1 を脱泡はく離㓮として検討した.このフロン ガスには構造中の $\mathrm{Br}$ にその効果があり, 試料溶融後に 少量吹きかけるだけでるつぼから気泡のないガラスビー ドが容易に取り出せることが分かった．操作性からもこ のフロンガスが適当と考えられ脱泡はく離剤として使用 することにした。

2.3.3 溶虽条件試料と融剂の配合割合について 重量比を $1: 6$ から $1: 18$ まで変化させ検討した結果, 試料の溶融が容易で, XRF 強度が十分に得られる重量 比 $1: 11$ とすることにした. 試料 $0.500 \mathrm{~g}$, 融剤 5.500 $\mathrm{g}$ をビード用るつぼに量り取り, 十分混合した後, 溶融 装置で溶融する，溶融及び摇動・焼どん・冷却の一連の 操作は自動化されている. 溶融に際し, 初めは粉体試料 が飛散しないように徐々に加熱し, 最終的に $1100{ }^{\circ} \mathrm{C}$ で 3 分間加熱するように設定した. 又前述したように焼 どん時にフロンガスを少量吹きかける。

\subsection{XRF 測定条件}

XRF 測定条件を Table 2 に示す. 岩石試料中で比 較的含有量が少なく, 又 XRF のピークとバックグラウ ンドの計数率の比が小さい元素に対しては 2 点によるバ ックグラウンドの除去処理をした. 合成標準試料 SS3 のガラスビードを用い，Table 2 に示した測定条件で 
Table 2 Analytical conditions for XRF

\begin{tabular}{|c|c|c|c|c|c|c|}
\hline Element & $2 \theta_{\mathbf{A}}$ & $2 \theta_{\mathbf{B}}$ & Crystal & Detector & Slit & Counting time/s \\
\hline $\mathrm{Si}$ & 144.46 & & $\operatorname{InSb}\left(\begin{array}{lll}1 & 1\end{array}\right)$ & $\mathrm{SC}$ & $F$ & 20 \\
\hline $\mathrm{Ti}$ & 86.07 & 84.90 & $\mathrm{LiF}(200)$ & $\mathrm{SC}$ & $\mathrm{F}$ & 20 \\
\hline $\mathrm{Al}$ & 145.05 & • & PET $\left(\begin{array}{lll}0 & 0 & 2\end{array}\right)$ & $\mathrm{PC}$ & $\mathrm{C}$ & 20 \\
\hline $\mathrm{Fe}$ & 57.52 & & $\mathrm{LiF} \quad(200)$ & $\mathrm{SC}$ & $\mathrm{F}$ & 20 \\
\hline $\mathrm{Mn}$ & 62.97 & $62.37, \quad 63.80$ & $\mathrm{LiF} \quad(200)$ & SC & $\mathrm{C}$ & 20 \\
\hline $\mathrm{Mg}$ & 45.28 & $44.04, \quad 47.44$ & TAP $\left(\begin{array}{lll}0 & 0 & 1\end{array}\right)$ & $\mathrm{PC}$ & $\mathrm{C}$ & 40 \\
\hline $\mathrm{Ca}$ & 113.04 & & $\mathrm{LiF}(200)$ & $\mathrm{PC}$ & $\mathrm{C}$ & 20 \\
\hline $\mathrm{Na}$ & 55.21 & $53.56, \quad 56.66$ & TAP $\left(\begin{array}{lll}0 & 0 & 1\end{array}\right)$ & $\mathrm{PC}$ & $\mathrm{C}$ & 40 \\
\hline $\mathrm{K}$ & 136.83 & $134.00,139.50$ & $\mathrm{LiF} \quad\left(\begin{array}{lll}2 & 0 & 0\end{array}\right)$ & $\mathrm{PC}$ & $\mathrm{C}$ & 20 \\
\hline $\mathrm{P}$ & 140.85 & $137.50,144.20$ & $\mathrm{Ge} \quad\left(\begin{array}{lll}1 & 1 & 1\end{array}\right)$ & $\mathrm{PC}$ & $\mathrm{C}$ & 40 \\
\hline
\end{tabular}

X-Ray tube : Rh target $(50 \mathrm{kV}, 50 \mathrm{~mA}) ; 2 \theta_{\mathbf{A}}: 2 \theta$ angle of analytical line; $2 \theta_{\mathbf{B}}: 2 \theta$ angle of background; $\mathrm{SC}$ : scintillation counter; PC : gas flow proportional counter; $\mathrm{F}:$ fine; $\mathrm{C}:$ coarse

10 元素を繰り返し測定したときの各 XRF 計数值の相 対標準偏差を求めたところ, 全元素について $1 \%$ 以内 であり，良好な測定が行われたことが分かった。

日常分析の管理のためにはX線強度を標準化する必要 がある.このため各元素について十分な XRF 強度が得 られ, しかも, 濃度が検量線の中心にある合成標準試料 SS3 のガラスビードを標準化試料として用い，XRF 装 置の長期的変動を補正することにした.

\section{3 結果及び考察}

\section{1 ガラスビードの再現性}

合成標準試料 SS3 を用いてガラスビードを 5 個作製 し, 各々について 10 元素の測定を行いXRF の計数值 の平均, 標準偏差及び相対標準偏差を求めた. この結果 を Table 3 に示す. この結果にはガラスビードの作製 条件の差異や XRF 測定の変動などを含む. Mn, P は 少量成分であるが，相対標準偏差は $1.40 \%$ と小さかっ た. 又ガラスビード内の偏析を検討するためガラスビー ドの上面と下面を測定したが，各元素の XRF 強度には

Table 3 Reproducibility of synthetic standard glass bead sample SS3 $(n=5)$

\begin{tabular}{crrc}
\hline Element & \multicolumn{1}{c}{$\overrightarrow{\boldsymbol{x}}$} & \multicolumn{1}{c}{$\boldsymbol{\sigma}$} & R.S.D., \% \\
\hline $\mathrm{Si}$ & 289937 & 663 & 0.23 \\
$\mathrm{Ti}$ & 11715 & 122 & 1.04 \\
$\mathrm{Al}$ & 50425 & 212 & 0.42 \\
$\mathrm{Fe}$ & 205188 & 1175 & 0.57 \\
$\mathrm{Mn}$ & 12759 & 185 & 1.40 \\
$\mathrm{Mg}$ & 15499 & 65 & 0.42 \\
$\mathrm{Ca}$ & 406649 & 943 & 0.23 \\
$\mathrm{Na}$ & 2925 & 22 & 0.75 \\
$\mathrm{~K}$ & 76975 & 286 & 0.37 \\
$\mathrm{P}$ & 6127 & 85 & 1.39 \\
\hline
\end{tabular}

$\bar{x}$ : average of $\mathrm{X}$-ray counts; $\sigma$ : standard deviation; R.S.D. : relative standard deviation
両者の差異はなく均一に溶融されていることが確認され た. 以上の結果からガラスビードの再現性は良好であり 合成標準試料に和ける試薬の混合が十分に行われ良質な ガラスビードが作製できることが確認された，又相対標 準偏差の結果から全元素について測定精度は良好と考え られる。

\section{2 合成標準試料と標準岩石試料の測定}

合成標準試料と標準岩石試料のガラスビードを用いて 10 元素の XRF 強度を測定した. 主成分元素である $\mathrm{SiO}_{2}$ と少量成分元素である $\mathrm{P}_{2} \mathrm{O}_{5}$ について XRF 強度 と濃度との関係を Fig. 1 及び 2 に示す．全試料より得

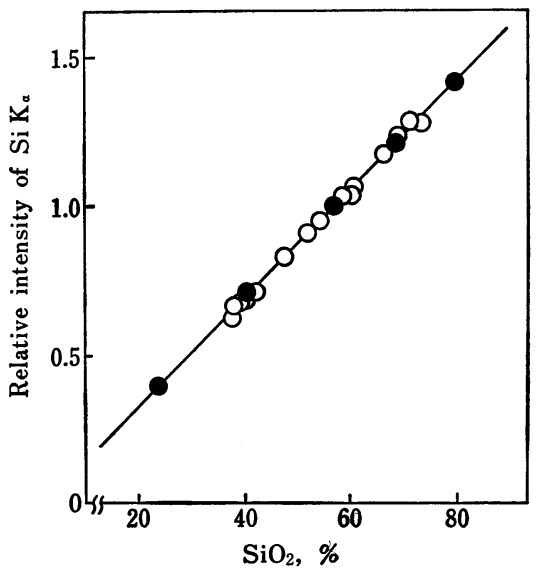

Fig. 1 Plot of XRF intensity against $\mathrm{SiO}_{2}$ concentration for rock standard and synthetic standard samples

$\bigcirc$ : rock standard sample; 1 : synthetic standard sample. Relative intensity given as intensity ratio of sample to synthetic standard sample SS-3. 


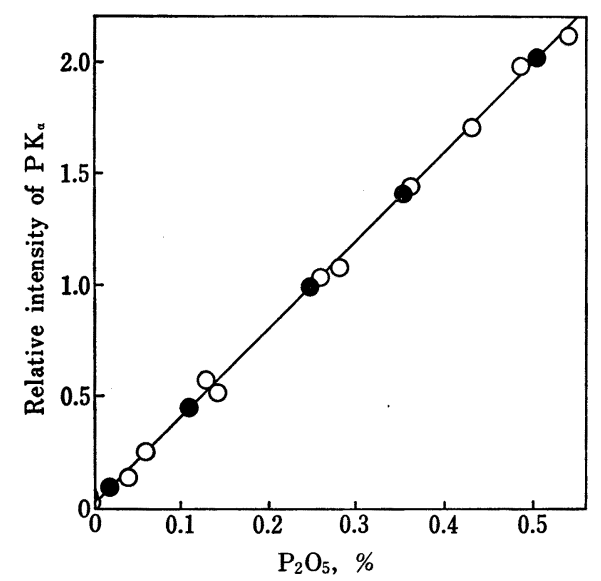

Fig. 2 Plot of XRF intensity against $\mathrm{P}_{2} \mathrm{O}_{5}$ concentration for rock standard and synthetic standard samples

$\bigcirc$ : rock standard sample; $:$ synthetic standard sample. Relative intensity given as intensity ratio of sample to synthetic standard sample SS-3.

られた一次回帰式からの正確度は, 濃度範囲が 23〜80\% の $\mathrm{SiO}_{2}$ で $0.33 \%, 0 \sim 0.5 \%$ の $\mathrm{P}_{2} \mathrm{O}_{5}$ で $0.01 \%$ 以下 であった．その他の元素についても同様の結果が得られ た.このことからマトリックス効果の補正なしに良好な 定量が行えることが分かった.

\section{3 合成標準試料を用いた標準岩石試料の定量}

合成試料を基準にして岩石標準試料の 10 成分の定量 をガラスビード法で行った．合成標準試料から検量線定 数を求め, XRF 装置の演算機能を用いてデータ解析を 行い濃度表示 $(w t \%)$ として結果を得た. 標準岩石試料
の定量結果の一例を Table 4 (JB-1, G-2) に示す. 合成標準試料の濃度範囲内では基準值に極めて近い結果 が得られたが，濃度範囲外では基準值に比べ誤差が大き かった．このため濃度範囲を広げた合成標準試料を作製 して, 広範㘫の岩石試料の定量を行うことにした. この ことは合成標準試料を用いることで, 任意の濃度範囲の 袷量線作成が可能であること，入手しにくい標準岩石試 料を用いなくても定量ができることを示している.

\section{4 強熱減量分の多い岩石試料の定量}

岩石のなかには試料中に水分, 二酸化炭素, 硫黄, 有 機物などを多く含む試料もあり，これらはガラスビード 作製時に揮散するため岩石試料の定量に大きな䛊差を与 える.このため, あらかじめ強熱減量を求め10), その強 熱処理を行った試料を用いてガラスビードを作製し，各 成分の定量を行い，強熱減量率を補正することにより， 各元素の濃度が求められる.この補正式は,

$$
W_{\mathrm{i}}=X_{\mathrm{i}}(100-L)(1 / 100)
$$

で表される，ここに， $W_{\mathrm{i}}$ は定量成分(i)の補正定量值， $X_{\mathrm{i}}$ は未補正定量値, $L$ は強熱減量 ( $\mathrm{wt} \%$ ) である.こ の方法を用いて，USGS の標準岩石試料である MAG1 と SGR-1 の定量を行った。 MAG-1 及び SGR-1 の強熱減量は 12.76 及び $41.67(\mathrm{wt} \%)$ であった。この 值を用いて, 補正を行った各元素の定量結果を Table 4 (MAG-1, SGR-1) 飞示す. 推奖値と良く一致した結 果が得られ, この方法が十分, 実用分析に用いられるこ とが分かった. 日常分析に执いては, 強熱減量の多い試 料も珍しくなくこの補正法を用いることにより種々の 岩石試料への適応範用が広がった.

Table 4 Comparison of XRF and recommended values of JB-1, G2, MAG-1 and SGR-1

\begin{tabular}{|c|c|c|c|c|c|c|c|c|c|c|c|c|}
\hline \multirow{2}{*}{ Oxide } & \multicolumn{3}{|c|}{$\mathrm{JB}-1^{\mathrm{a})}$} & \multicolumn{3}{|c|}{$\mathrm{G}-2^{\mathrm{a})}$} & \multicolumn{3}{|c|}{ MAG-1b) } & \multicolumn{3}{|c|}{ SGR-1b) } \\
\hline & XRF & r.v. & d. & XRF & r.v. & d. & XRF & r.v. & d. & XRF & r.v. & d. \\
\hline $\mathrm{SiO}_{2}$ & 51.30 & 51.18 & 0.12 & 69.24 & 69.11 & 0.13 & 50.91 & 51.19 & -0.28 & 28.34 & 28.30 & 0.04 \\
\hline $\mathrm{TiO}_{2}$ & 1.34 & 1.34 & 0.00 & 0.53 & 0.50 & 0.03 & 0.74 & 0.75 & -0.01 & 0.25 & 0.24 & 0.01 \\
\hline $\mathrm{Al}_{2} \mathrm{O}_{3}$ & 14.69 & 14.53 & 0.16 & 16.04 & 15.40 & 0.64 & 16.29 & 16.46 & -0.17 & 6.46 & 6.49 & -0.03 \\
\hline $\mathrm{Fe}_{2} \mathrm{O}_{3}(\mathrm{~T})$ & 8.98 & 8.96 & 0.02 & 2.58 & 2.65 & -0.07 & 6.93 & 6.98 & -0.05 & 2.99 & 2.98 & 0.01 \\
\hline $\mathrm{MnO}$ & 0.15 & 0.15 & 0.00 & 0.03 & 0.03 & 0.00 & 0.10 & 0.10 & 0.00 & 0.03 & 0.03 & 0.00 \\
\hline $\mathrm{MgO}$ & 7.63 & 7.74 & -0.11 & 0.70 & 0.76 & -0.06 & 2.97 & 3.13 & -0.16 & 4.41 & 4.57 & -0.16 \\
\hline $\mathrm{CaO}$ & 9.10 & 9.24 & -0.14 & 1.91 & 1.94 & -0.03 & 1.39 & 1.38 & 0.01 & 8.17 & 8.32 & -0.15 \\
\hline $\mathrm{Na}_{2} \mathrm{O}$ & 2.71 & 2.80 & -0.09 & 4.31 & 4.07 & 0.24 & 3.53 & 3.91 & -0.38 & 2.84 & 3.02 & -0.18 \\
\hline $\mathrm{K}_{2} \mathrm{O}$ & 1.64 & 1.44 & 0.20 & 4.35 & 4.51 & -0.16 & 3.66 & 3.72 & -0.06 & 1.59 & 1.63 & -0.04 \\
\hline $\mathrm{P}_{2} \mathrm{O}_{5}$ & 0.26 & 0.26 & 0.00 & 0.13 & 0.14 & -0.01 & 0.16 & 0.18 & -0.02 & 0.28 & 0.29 & -0.01 \\
\hline
\end{tabular}

a) $n=3$, b) $n=2$; All values given as $\mathrm{wt} \% ; \mathrm{Fe}_{2} \mathrm{O}_{3}(\mathrm{~T})$ : total $\mathrm{Fe}$ as $\mathrm{Fe}_{2} \mathrm{O}_{8} ; \mathrm{XRF}$ : this work; r.v. : recommended value; $d:(\mathrm{XRF}$ value $)-($ r.v. $)$ 


\section{5 カラスビードの保存}

ガラスビードは粉末の加圧成型試料に比べて保存性は 良いが，長期間，大気中に放置すると表面が曇る. 曇っ た表面を IR で測定した結果, 水酸基が多く存在するこ とが確認され, 大気中の水分によって加水分解し, 水酸 基が形成されたものと推定される. 軽元素は XRF 測定 の際, 酸素による吸収のため大きな妨害を受ける. 実 際に曇ったガラスビードを测定したところ，軽元素の XRF 強度は著しく低下した.

現在, ガラスビードの保存には乾燥デシケーターを使 用しているが，頻繁に出し入れしていると，表面に量り を生じてくる. この曇ったガラスビードを再溶融するこ とにより再利用できるかどうか検討を行った．一つのガ ラスビードを用いて，XRF 測定と再溶融を 5 回繰り返 し, 再溶融の回数に対して, 初めの XRF 強度を 1 とし たときの強度変化を測定した. 結果を Table 5 に示 す. 各元素とも再溶融による XRF 強度变化は無視でき る程度で, 鼻りを生じたガラスビードの再生が可能であ ることが分かった. しかし，ガラスビードが変質しない ように取り扱いや保存には十分注意することが大切であ る.
Table 5 Effect of re-fusion on XRF intensity

\begin{tabular}{lccccc}
\hline \multirow{2}{*}{ Element } & \multicolumn{5}{c}{ Number of re-fusion times (run) } \\
\cline { 2 - 6 } & 1 & 2 & 3 & 4 & 5 \\
\hline $\mathrm{Si}$ & 1.00 & 1.00 & 1.00 & 1.01 & 1.02 \\
$\mathrm{Ti}$ & 1.00 & 1.00 & 1.01 & 1.00 & 1.02 \\
$\mathrm{Al}$ & 1.00 & 1.00 & 1.01 & 1.00 & 1.01 \\
$\mathrm{Fe}$ & 1.00 & 1.00 & 1.00 & 1.01 & 1.00 \\
$\mathrm{Mn}$ & 1.00 & 1.01 & 1.00 & 1.00 & 1.02 \\
$\mathrm{Mg}$ & 1.00 & 0.98 & 0.99 & 1.01 & 1.00 \\
$\mathrm{Ca}$ & 1.00 & 1.00 & 1.00 & 1.01 & 1.01 \\
$\mathrm{Na}$ & 1.00 & 1.02 & 0.99 & 1.01 & 1.00 \\
$\mathrm{~K}$ & 1.00 & 0.99 & 0.98 & 0.97 & 0.98 \\
$\mathrm{P}$ & 1.00 & 1.00 & 1.01 & 1.00 & 1.03 \\
\hline
\end{tabular}

All values given as relative $\mathrm{XRF}$ intensity against 1 run.

\section{6 実試料の分析}

GSJ 及び USGS から新しく発行された標準岩石試料 の分析を行った. 結果を Table 6 及び 7 亿示す.

本法による試料の処理能力は 1 作業者で 1 日に約 20 個のガラスビードが作製でき，XRF 装置を夜間自動運 転することで翌朝までに定量結果が得られる。ただし， 強熱减量を測定する場合はその作業時間が必要になる。

Table 6 Analytical results of GSJ rock standard samples

\begin{tabular}{|c|c|c|c|c|c|c|c|}
\hline Name & JG-1a & $\mathrm{JG}-2$ & JG-3 & JB-1a & $\mathrm{JA}-2$ & $\mathrm{JA}-3$ & $\mathrm{JP}-1$ \\
\hline $\mathrm{SiO}_{2}$ & 72.40 & 76.72 & 66.44 & 52.15 & 56.16 & 61.66 & 41.94 \\
\hline $\mathrm{TiO}_{2}$ & 0.26 & 0.05 & 0.48 & 1.27 & 0.68 & 0.69 & 0.02 \\
\hline $\mathrm{Al}_{2} \mathrm{O}_{8}$ & 14.46 & 12.73 & 15.59 & 14.41 & 15.68 & 15.74 & 0.83 \\
\hline $\mathrm{Fe}_{2} \mathrm{O}_{8}(\mathrm{~T})$ & 1.94 & 0.94 & 3.72 & 9.07 & 6.35 & 6.69 & 8.41 \\
\hline $\mathrm{MnO}$ & 0.06 & 0.02 & 0.07 & 0.14 & 0.11 & 0.11 & 0.11 \\
\hline $\mathrm{MgO}$ & 0.73 & 0.07 & 1.80 & 7.69 & 7.25 & 3.69 & 44.74 \\
\hline $\mathrm{CaO}$ & 2.09 & 0.68 & 3.63 & 9.20 & 6.15 & 6.21 & 0.57 \\
\hline $\mathrm{Na}_{2} \mathrm{O}$ & 3.65 & 3.70 & 4.02 & 2.82 & 3.02 & 3.53 & 0.05 \\
\hline $\mathrm{K}_{2} \mathrm{O}$ & 3.91 & 4.65 & 2.59 & 1.40 & 1.80 & 1.40 & $<0.01$ \\
\hline $\mathrm{P}_{2} \mathrm{O}_{3}$ & 0.07 & $<0.01$ & 0.12 & 0.25 & 0.15 & 0.11 & $<0.01$ \\
\hline
\end{tabular}

All values given as $w t \%$. $\mathrm{Fe}_{2} \mathrm{O}_{3}(\mathrm{~T})$ : total $\mathrm{Fe}$ as $\mathrm{Fe}_{2} \mathrm{O}_{3} ; n=2$

Table 7 Analytical results of USGS rock standard samples

\begin{tabular}{lrrrrrrrrr}
\hline $\mathrm{Name}$ & BHVO-1 & \multicolumn{1}{c}{ BIR-1 } & \multicolumn{1}{c}{ DNC-1 } & \multicolumn{1}{c}{ QLO-1 } & RGM-1 & SCo-1 & SDC-1 & STM-1 & W-2 \\
\hline $\mathrm{SiO}_{2}$ & 49.59 & 47.59 & 46.71 & 65.56 & 73.12 & 63.04 & 66.22 & 59.57 & 52.56 \\
$\mathrm{TiO}_{2}$ & 2.70 & 0.94 & 0.49 & 0.61 & 0.28 & 0.60 & 1.00 & 0.15 & 1.06 \\
$\mathrm{Al}_{2} \mathrm{O}_{3}$ & 13.55 & 15.40 & 18.20 & 16.48 & 14.01 & 13.87 & 16.00 & 18.40 & 15.16 \\
$\mathrm{Fe}_{2} \mathrm{O}_{3}(\mathrm{~T})$ & 12.30 & 11.58 & 10.22 & 4.29 & 1.81 & 5.13 & 6.84 & 5.24 & 10.99 \\
$\mathrm{MnO}$ & 0.16 & 0.17 & 0.14 & 0.09 & 0.04 & 0.06 & 0.12 & 0.23 & 0.16 \\
$\mathrm{MgO}$ & 7.13 & 9.62 & 10.09 & 1.05 & 0.32 & 2.71 & 1.72 & 0.15 & 6.35 \\
$\mathrm{CaO}$ & 11.36 & 13.34 & 11.38 & 3.12 & 1.18 & 2.54 & 1.42 & 1.12 & 10.83 \\
$\mathrm{Na}_{2} \mathrm{O}$ & 2.33 & 1.68 & 1.94 & 4.17 & 3.83 & 0.86 & 2.00 & 8.52 & 2.19 \\
$\mathrm{~K}_{2} \mathrm{O}$ & 0.53 & 0.01 & 0.23 & 3.63 & 4.39 & 2.73 & 3.29 & 4.29 & 0.62 \\
$\mathrm{P}_{2} \mathrm{O}_{3}$ & 0.28 & 0.02 & 0.06 & 0.26 & 0.04 & 0.20 & 0.14 & 0.14 & 0.12 \\
\hline
\end{tabular}

All values given as $w t \% . \quad \mathrm{Fe}_{2} \mathrm{O}_{3}(\mathrm{~T})$ : total $\mathrm{Fe}$ as $\mathrm{Fe}_{2} \mathrm{O}_{3} ; n=2$ 
本研究を行うに当たり御助言, 並びに貴重な標準試料 を提供していただいた東北大学の加藤豊明教授及び地質 調査所の安藤 厚博士に深謝致します.

$$
\left(\begin{array}{l}
1983 \text { 年 } 10 \text { 月, 日本分析化学会 } \\
\text { 第 } 32 \text { 年会において一部発表 }
\end{array}\right)
$$

\section{交献}

1）後藤隼次，大野正一：地質調査所月報，32，21 (1981).

2）後藤隼次，金谷 弘：地質調査所月報，36, 453 (1985).

3) K. K. Nielson, C. V. Rogers : Adv. X-ray Anal., 29, 587 (1986).

4) K. Norrish, J. T. Hutton : Geochim. Cosmochim. Acta, 33, 431 (1969).

5）服部 仁：地質調査所月報，22，103（1971）。

6）大森貞子, 大森江い：地質調査所月報，27，195 (1976).

7）大森貞子：地質調査所月報，27，425（1976).

8) K. I. Mahan, D. E. Leyden : Anal. Chim. Acta, 147, 123, (1983).

9) 田中 勇, 大柣 孝, 佐藤公隆: 分析化学, 28, 293 (1979)

10）地質調査所技術部化学課 : “地球科学的試料の化 学分析法 2”, p. 287 (1978), （工業技術院地質 調査所)。

šs

XRF determination of major elements in rocks using glass bead method with synthetic standard samples. Akira Yoshioka, Takao Sekine, Hidemistu Yoshida and Koichi Nomura (Central Research Institute, Mitsubishi Metal Corporation, 1-297, Kitabukurocho, Omiya-shi, Saitama 330)

A simple and rapid method for the determination of major elements in rocks by XRF using the glass bead technique has been investigated. Calibration curves were made by using synthetic standard glass bead samples. The preparation of the synthetic standard samples was as follows. High-purity compounds containing desired concentrations of elements were mixed well and then heated at $1000^{\circ} \mathrm{C}$ in air. A sample $(0.500 \mathrm{~g})$ was fused with $\mathrm{Li}_{2} \mathrm{~B}_{4} \mathrm{O}_{7}(5.500 \mathrm{~g})$ in a $\mathrm{Pt}-5 \%$ Au crucible at $1100^{\circ} \mathrm{C}$ for $3 \mathrm{~min}$. A small amount of monobromtrifluoromethane gas $\left(\mathrm{CBrF}_{3}\right)$ was sprayed on the melt to remove air bubbles and to allow the melt to be removed readily from the crucible. The synthetic standard glass bead smples had a good reproducibility and linear calibration curves were obtained without matrix correction. The proposed method was applied to the determination of $\mathrm{Si}, \mathrm{Ti}, \mathrm{Al}, \mathrm{Fe}, \mathrm{Mn}, \mathrm{Mg}$, $\mathrm{Ca}, \mathrm{Na}, \mathrm{K}$ and $\mathrm{P}$ in various rock samples. The analytical results of rock standard samples showed good agreement with the recommended values.

(Received June 18, 1988)

\section{Keyword phrases}

XRF analysis by glass bead sample; synthetic standard; determination of $\mathrm{Si}, \mathrm{Ti}, \mathrm{Al}, \mathrm{Fe}, \mathrm{Mn}, \mathrm{Mg}, \mathrm{Ca}$, $\mathrm{Na}, \mathrm{K}$ and $\mathrm{P}$ in rock; correction for loss on ignition. 